\title{
Spatio-temporal analysis of urban air pollutants throughout China during 2014-2019
}

\author{
Chenkai Zhao ${ }^{1}$ - Ying Sun ${ }^{1} \cdot$ Yaping Zhong ${ }^{1} \cdot$ Senhao Xu ${ }^{1} \cdot$ Yue Liang ${ }^{1} \cdot$ Shu Liu ${ }^{2} \cdot$ Xiaodong He $^{3} \cdot$ Jinghai Zhu $^{1}$. \\ Takayuki Shibamoto ${ }^{4} \cdot$ Miao He $^{1}$
}

Received: 1 September 2020 / Accepted: 6 May 2021 / Published online: 14 May 2021

(C) The Author(s), under exclusive licence to Springer Nature B.V. 2021

\begin{abstract}
Air pollution control has become the top priority of China's "green development" concept since 2013. The Chinese government has enacted a range of policies and statutes to control contaminant emissions and improve air quality. On the basis of the national air quality ground observation database, the spatial and temporal distribution of air quality index value (AQI), fine particulate matter $\left(\mathrm{PM}_{2.5}\right)$, coarse particles $\left(\mathrm{PM}_{10}\right)$, sulfur dioxide $\left(\mathrm{SO}_{2}\right)$, nitrogen dioxide $\left(\mathrm{NO}_{2}\right)$, carbon monoxide $(\mathrm{CO})$, and ozone $\left(\mathrm{O}_{3}\right)$ were explored in 336 cities throughout China from 2014 to 2019. AQI and most pollutants (except $\mathrm{O}_{3}$ ) decreased in concentrations from 2014 to 2019. In 2019, all cities except Henan reached the level 2 of the ambient air quality index, and six cities had a lower ambient air quality index and reached the level 1. Spatially, higher pollutant concentrations were concentrated in large city clusters, whereas the areas with high $\mathrm{O}_{3}$ concentration were found across the country. Furthermore, central heating was shown to have a negative impact on air quality. The observed $\mathrm{AQI}$ value, $\mathrm{PM}_{2.5}, \mathrm{PM}_{10}, \mathrm{SO}_{2}, \mathrm{NO}_{2}$, and $\mathrm{CO}$ concentrations were highest in north and northwest China and Henan province in central China. The correlations among pollutants suggest that the main sources of pollutants are fossil fuel combustion, industrial production, and motor vehicle emissions. The influence of meteorological factors on air quality, long-distance transportation, and the transformations of pollutants should be explored in future research.
\end{abstract}

Keywords Urban air pollutants $\cdot$ Spatial $\cdot$ Temporal $\cdot$ Fuel emission $\cdot$ Central heating

\section{Introduction}

It has been widely demonstrated that particulate matter (PM) and gaseous pollutants in the atmosphere can enter the human body through the respiratory system, digestive system, or other channels and subsequently affect health. Coarse particles $\left(\mathrm{PM}_{10}\right)$ and fine particulate matter $\left(\mathrm{PM}_{2.5}\right)$ increase the risk of respiratory diseases, such as chronic obstructive pulmonary

Miao He

mhermu@163.com

1 Department of Environmental Health, School of Public Health, Key Laboratory of Environmental Health Damage Research and Assessment, China Medical University, Shenyang 110122, Liaoning Province, China

2 Ecological Environment Monitoring Center, Shenyang 110000, Liaoning Province, China

3 Ecological Environment Monitoring Center, Benxi City 117000 , Liaoning Province, China

4 Department of Environmental Toxicology, University of California, Davis, CA 95616, USA diseases (COPD) (Huang et al. 2019), asthma (Alotaibi et al. 2019), bronchitis, and lung cancer. Gaseous pollutants, such as sulfur dioxide $\left(\mathrm{SO}_{2}\right)$, could increase the risk of cardiovascular disease (Yap et al. 2019). Moreover, ozone $\left(\mathrm{O}_{3}\right)$ is associated with adverse cardiovascular effects (Xia et al. 2018) and could increase daily mortality rates (Yin et al. 2017).

Rapid industrialization, urbanization, and rural modernization in recent years have caused severe air pollution in China. Many cities are facing serious environmental problems. In the first quarter of 2013, China suffered from persistent and severe air pollution (Huang et al. 2014). Therefore, the Chinese government adopted a series of measures to improve air quality. In September 2013, the Air Pollution Prevention and Control Action Plan (APPCAP) was disseminated. The goal of this plan was to improve air quality in heavily polluted environments (Huang et al. 2018). In January 2015, the environmental protection law, regarded as an important milestone in China's air pollution prevention and control, was officially implemented (Song et al. 2017). In 2016, China joined the Paris Agreement on climate change and promised to reduce hazardous emissions from coal-fired power plants by $50 \%$ by 2020, establish automatic real-time air quality monitoring 
systems, develop new energy technology, and promote renewable energy policies (Tambo et al. 2016). In December 2016, China issued the thirteenth 5 -year eco-environmental protection plan, which promised that $\mathrm{SO}_{2}$ and carbon monoxide (CO) concentrations in prefecture-level cities will reach the standard by 2021 , whereas the PM and nitrogen dioxide $\left(\mathrm{NO}_{2}\right)$ concentration would be significantly decreased (Ministry of Ecology and Environment of the People's Republic of China 2012). In 2018, China enacted the environmental protection tax law to raise awareness of environmental protection within Chinese society (The National People's Congress of the People's Republic of China 2018).

Previous studies on the temporal and spatial distribution of pollutants in China have several limitations. One issue is that several studies are limited to a short experimental period. For example, $\mathrm{Li}$ ( $\mathrm{Li}$ et al. 2019) examined air pollution data for 2015-2016 and applied path analysis to reveal that temperature, wind speed, and precipitation were major factors affecting air pollutant concentrations. Another issue is that several studies only focus on a single factor. For example, Zeng (Zeng et al. 2019) used observations from national air quality stations to analysis the spatial-temporal variation of pollutants and found that the $\mathrm{SO}_{2}, \mathrm{NO}_{\mathrm{x}}$ and $\mathrm{PM}$ concentrations decreased, but the $\mathrm{O}_{3}$ concentration increased. Moreover, China has been shown to be in transition from $\mathrm{SO}_{2}$-dominated to $\mathrm{NO}_{\mathrm{x}}$ - and $\mathrm{O}_{3}$-dominated air pollution. Analyses with larger study area have also been reported. Fan (Fan et al. 2020) conducted a study on the spatial and temporal variations of the six criteria pollutants $\left(\mathrm{PM}_{2.5}, \mathrm{PM}_{10}, \mathrm{SO}_{2}, \mathrm{NO}_{2}, \mathrm{CO}\right.$, and $\mathrm{O}_{3}$ ) in 300 cities during 2014-2018 and found that $\mathrm{PM}, \mathrm{SO}_{2}$, $\mathrm{NO}_{2}$, and $\mathrm{CO}$ concentrations decreased significantly. Meanwhile, the North China Plain and Central-Western Xinjiang were the areas identified to be the most seriously polluted.

China is a vast country with various disparities in areas such as economic development, climate type, landform, and resource endowment. These phenomena have resulted in large differences in pollution levels among the provinces and across the seasons (Cui et al. 2019; Lu et al. 2019; Yao et al. 2019). Furthermore, extremely low winter temperatures in the northern region have led to a strong demand for central heating, which could be an important source of air pollution in winter. To explore the spatial and temporal variations characteristic of air pollution in China in the present study, air pollutant concentration data for 336 prefecture-level cities in China were examined for the 2014-2019 period. The purposes of our investigation were to (1) observe the trends in variation of the air quality index (AQI) value and PM and gaseous pollutant concentrations, (2) elucidate the discrepancies in the spatial distributions of AQI values and air pollutant concentrations, (3) compare the effects of different heating methods on air quality, and (4) analyze the major sources of air pollution in China. We intend to provide some comprehensive information on air pollution and contribute to the prevention and control of air pollution in China.

\section{Material and methods}

\section{Study area}

To evaluate the overall air quality status in China, we analyzed ambient monitoring data of $\mathrm{PM}_{2.5}, \mathrm{PM}_{10}, \mathrm{SO}_{2}$, $\mathrm{NO}_{2}, \mathrm{CO}$, and $\mathrm{O}_{3}$ in 336 prefecture-level cities from January $1^{\text {st }}, 2014$, to December $31^{\text {st }}$, covering 31 provinces, autonomous regions, and municipalities in mainland China (except Hong Kong, Macao, and Taiwan). To present the regional variation of air quality, the 31 provinces were divided into 7 regions based on their natural geographical characteristics, i.e., Central, East, North, Northeast, Northwest, South, and Southwest. The cities, regions, and their location were illustrated in Fig. 1.

According to the heating requirement, the government divides China into a central heating area and a non-central heating area by the Qinling Mountains-Huaihe River Line (Fig. S1). The heating season usually lasts from late autumn to early spring in central heating area. To estimate the air pollution caused by heating emissions, 14 cities were selected as the sample cities, with 7 located in the central heating area and the rest located in the non-central heating area. The sample cities are selected based on the following criterions: (a) The cities are well known in each region; (b) the cities can represent the meteorology distribution characteristic of each region; (c) the cities are the reprehensive of different levels of average pollutant concentrations in China; and (d) each geographical area has 2 sample cities. The names of sample cities were listed as follow: Beijing and Shijiazhuang in the North region, Shenyang and Changchun in the Northeast region, Shanghai and Nanjing in the East region, Zhengzhou and Wuhan in the Central region, Guangzhou and Haikou in the South region, Chengdu and Chongqing in the Southwest region, and Xi'an and Urumqi in the Northwest region. Details about 14 sample cities were shown in Table S1.

\section{Data collection}

Daily AQI value and the real-time hourly concentrations of $\mathrm{PM}_{2.5}, \mathrm{PM}_{10}, \mathrm{SO}_{2}, \mathrm{NO}_{2}, \mathrm{CO}$, and 8-h averaged peak $\mathrm{O}_{3}$ $\left(8-\mathrm{h}_{3}\right.$ ) were downloaded from the website of Ministry of Ecology and Environment of the People's Republic of China [http://113.108.142.147:20035]. Since the new technical regulation for ambient air quality index (HJ6332012) (Ministry of Ecology and Environment of People's Republic of China 2012) has been executed, the air quality data of six criteria pollutants at individual monitoring site 


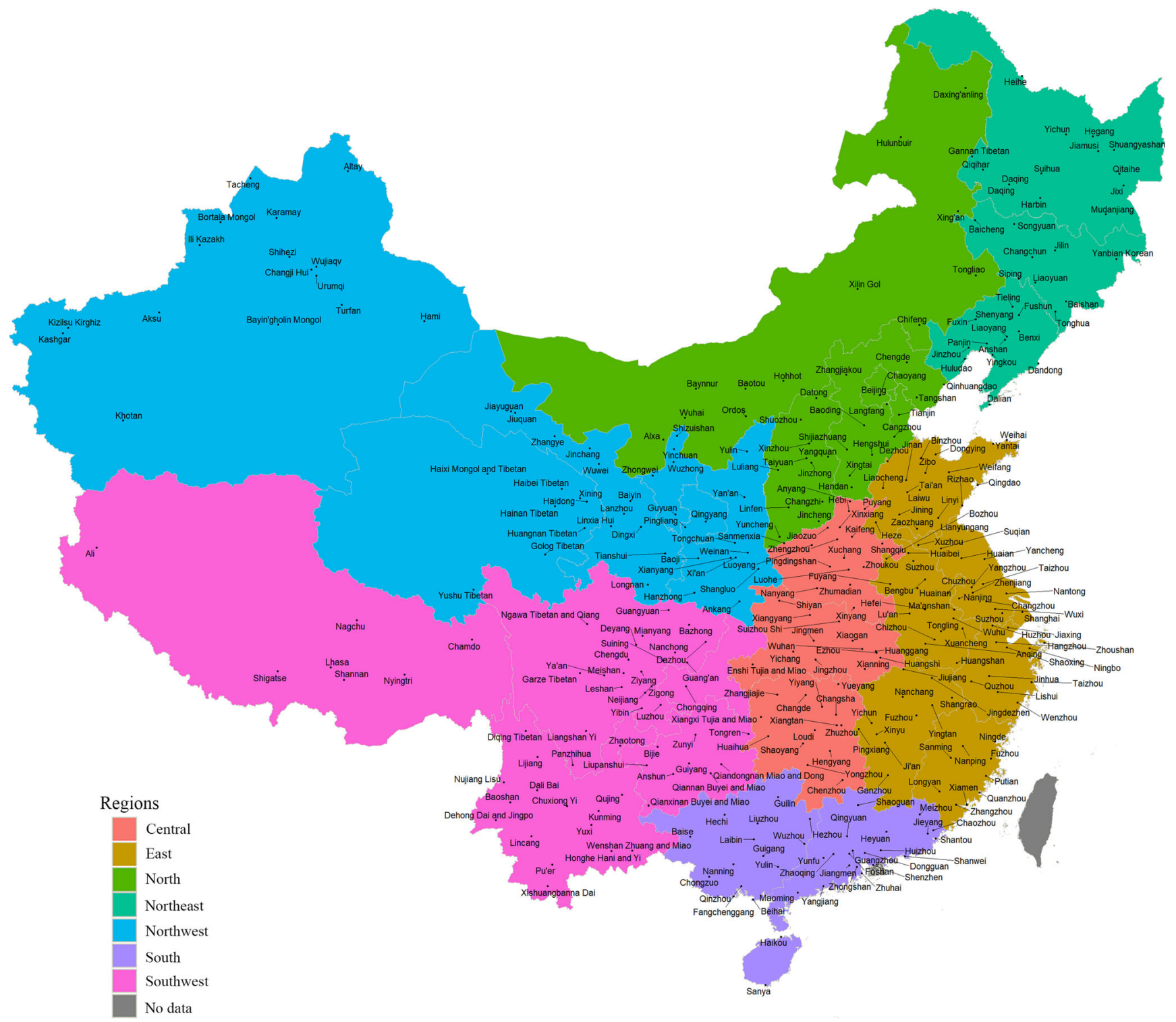

Fig. 1 The distribution of 336 cities and classification of seven geographical regions in China

for major cities have been published through the website. To date, the monitoring sites have covered Mainland China, while the data of six criteria pollutants in 161 cities were lacked from January $1^{\text {st }}, 2014$, to December $31^{\text {st }}$, 2015 because many monitoring sites had not been established before 2015. According to the technical regulation (HJ633-2012), AQI is divided into six levels. The degree of air quality was graded on the following scale: 1 , excellent; 2 , good; 3 , mild air pollution; 4 , moderate air pollution; 5 , heavy air pollution; and 6 , severe air pollution. "Excellent" was defined as AQI from 0 to 50; "good" was defined as AQI from 51 to 100 ; "mild air pollution" was defined as AQI from 101 to 150; "moderate air pollution" was defined as AQI from 151 to 200; "heavy air pollution" was defined as AQI from 201 to 300; and "severe air pollution" was defined as AQI more than 300.

\section{Data analysis}

We first calculated the annual average value or concentrations of AQI and six criteria pollutants $\left(\mathrm{PM}_{2.5}, \mathrm{PM}_{10}, \mathrm{SO}_{2}, \mathrm{NO}_{2}\right.$, $\mathrm{CO}$, and $\mathrm{O}_{3}$ ) for the whole country, the seven regions, and the 31 provinces. Analysis of variance (ANOVA) was used to compare the differences in annual average concentrations on the countrywide and seven regional scales. Tukey HSD was used for multiple comparison.

Based on the daily AQI values and six criteria pollutants concentrations of each city, a series of time-series boxplots were drawn to describe their temporal distribution. In order to better present the data distribution and probability density, a violin chart was superimposed on each month's box charts. A fitting line, which reflects the trend of these values over time, was added to each plot. The fitting method was generalized 
additive model, and the smoothing function was natural cubic splines.

Subsequently, the annual average concentrations of six criteria from the 31 provinces were used to draw a series of statistical maps to describe the spatial distribution over time. The annual scale was unified to better present the variation trends in air quality.

To investigate the impact of heating emissions on air quality, the Levene's test for the homogeneity of variance was used first in 14 selected sample cities, after which a multivariate analysis of variance (MANOVA) was used to analyze the influence of heating method (with or without central heating) and heating period (heating period and non-heating period) on air quality. Finally, a two-sample t-test was performed in 14 cities. The results were presented in a bar-plot with error bar.

The last part of our study was to analyze the source of pollutants. First, a Shapiro-Wilk normality test was conducted for particulate matters and gaseous pollutants in each city. For those data that did not accord with the normal distribution, the Spearman rank correlation was used to calculate the correlation coefficient among variables. General linear correlation was performed for those data that accord with a normal distribution. Finally, the correlation matrix was drawn.

The statistical tests were two-sided, and $p$ values $<0.05$ were considered statistically significant; in the Levene's homogeneity test, $p$ value $<0.10$ was considered statistically significant. All analyses and pictures were performed or drawn using R software (Version 3.6.1) (R Core Team 2020).

\section{Results}

\section{Temporal variation of urban air pollutants in China}

On the basis of individual ANOVA analysis, the annual average variations of six criteria pollutants changed significantly ( $p<0.05$ prior to adjustment for multiple comparisons) over the 6-year period (Table 1). Compared with 2014, the AQI value and the $\mathrm{PM}_{2.5}, \mathrm{PM}_{10}, \mathrm{SO}_{2}, \mathrm{NO}_{2}$, and $\mathrm{CO}$ concentrations decreased in 2019 by $28.7 \%, 38.0 \%, 34.1 \%, 67.9 \%, 24.9 \%$, and $34.4 \%$, respectively. The $\mathrm{O}_{3}$ concentration increased significantly from 2014 to 2018 and decreased slightly in 2019 . Overall, the $\mathrm{O}_{3}$ concentration increased $12.4 \%$ between 2014 and 2019.

The annual average variation of AQI values and the six criteria pollutants in the seven geographic regions are presented in Fig. 2, and more detailed information were summarized in Table S2. The variation patterns were similar among the seven regions; however, some regions showed some differences; for example, the PM concentration in northeast and central China increased significantly in 2018-2019 ( $p<$ 0.05), and the $\mathrm{O}_{3}$ concentration in south China declined significantly from 2014 to 2015 and then increased from 2015 to 2019.

The monthly average variation trends of the AQI value and six pollutants in the 14 sample cities are shown in Fig. 3. Those of the remaining cities are shown in Figs. S2-S35. The AQI value and pollutants other than $\mathrm{O}_{3}$ demonstrated significant seasonal variations with high values in winter and low values in summer. However, the seasonal variation of $\mathrm{O}_{3}$ and $\mathrm{NO}_{2}$ in Haikou was contrary to those in other cities; that is, $\mathrm{NO}_{2}$ concentration was higher in summer and $\mathrm{O}_{3}$ concentration was higher in winter.

\section{Spatial variation of urban air pollutants in China}

Figure 4 shows the spatial distribution maps of the annual average AQI values and PM and gaseous pollutant concentrations from 2014 to 2019 . The country was effectively divided into high pollutant concentration areas in the east and low pollutant concentration areas in the west by the $\mathrm{Hu}$ Huanyong line (black line in Fig. 4), which marks the striking difference in the distribution of the country's population. There was a notable reduction of AQI value and $\mathrm{PM}_{2.5}$, $\mathrm{PM}_{10}, \mathrm{SO}_{2}, \mathrm{NO}_{2}$, and $\mathrm{CO}$ concentration over the study period in large city clusters (the Beijing-Tianjin-Hebei region (BTH); Yangtze River Delta (YRD); Pearl River Delta (PRD); Sichuan-Chongqing (CY); and Liaoning, Jilin, Shanxi, Shaanxi, and Gansu provinces), but the pollutant concentrations were still the highest compared with other areas in the same period. It is worth noting that the $\mathrm{PM}_{10}$ concentration in Xinjiang Uygur increased significantly $(p<0.05)$ from 2015 to 2018. In Shandong, Henan, Jiangsu, Anhui, Shanghai, Qinghai, and Tibet, the $\mathrm{O}_{3}$ concentration was higher than that of other provinces in the same period.

Summaries of the annual average value of AQI and six criteria pollutants in the 31 provinces according to the Technical Regulation on Ambient Air Quality Index (HJ633-2012) were shown in Table S3 (Ministry of Ecology and Environment of People's Republic of China 2012). The highest AQI value was found in Hebei (133.92) in 2014, and the lowest value was found in Hainan (33.02) in 2019. By 2019, only Henan province failed to reach the level 2, and six cities had reached the level 1.

With reference to the ambient air quality standards (GB 3095-2012) (Ministry of Ecology and Environment of the People's Republic of China 2012), the highest concentration of $\mathrm{PM}_{2.5}$ was found in Hebei $\left(93.18 \mu \mathrm{g} / \mathrm{m}^{3}\right)$ in 2014 , and the lowest concentration was found in Tibet $\left(10.72 \mu \mathrm{g} / \mathrm{m}^{3}\right)$ in 2019. By 2019, Hainan and Tibet reached the grade I $(<15$ $\left.\mu \mathrm{g} / \mathrm{m}^{3}\right)$ standard, and 14 provinces reached the grade II standard $\left(<35 \mu \mathrm{g} / \mathrm{m}^{3}\right)$.

Similar to $\mathrm{PM}_{2.5}$, the highest annual average concentration of $\mathrm{PM}_{10}$ was found in Hebei $\left(163.13 \mu \mathrm{g} / \mathrm{m}^{3}\right)$ in 2014 , and the lowest concentration was found in Tibet $\left(24.80 \mu \mathrm{g} / \mathrm{m}^{3}\right)$ in 
Table 1 Annual average of AQI and 6 criteria pollutants (including $\mathrm{PM}_{2.5}, \mathrm{PM}_{10}, \mathrm{SO}_{2}, \mathrm{NO}_{2}, \mathrm{CO}$, and $8 \mathrm{~h} \mathrm{O}_{3}$ ) of 336 cities in China from 2014 to 2019

\begin{tabular}{llllllll}
\hline & AQI & $\mathrm{PM}_{2.5}\left(\mu \mathrm{g} / \mathrm{m}^{3}\right)$ & $\mathrm{PM}_{10}\left(\mu \mathrm{g} / \mathrm{m}^{3}\right)$ & $\mathrm{SO}_{2}\left(\mu \mathrm{g} / \mathrm{m}^{3}\right)$ & $\mathrm{NO}_{2}\left(\mu \mathrm{g} / \mathrm{m}^{3}\right)$ & $\mathrm{CO}\left(\mathrm{mg} / \mathrm{m}^{3}\right)$ & $\mathrm{O}_{3}\left(\mu \mathrm{g} / \mathrm{m}^{3}\right)$ \\
\hline 2014 & $92.01 \pm 55.27$ & $60.87 \pm 47.80$ & $103.95 \pm 75.95$ & $33.70 \pm 33.06$ & $35.78 \pm 19.06$ & $1.21 \pm 0.68$ & $53.49 \pm 28.70$ \\
2015 & $78.43 \pm 49.12$ & $48.87 \pm 40.62$ & $85.38 \pm 71.13$ & $24.27 \pm 26.43$ & $28.18 \pm 17.24$ & $1.08 \pm 0.69$ & $55.01 \pm 28.24$ \\
2016 & $76.27 \pm 48.82$ & $46.91 \pm 42.62$ & $82.80 \pm 84.62$ & $21.58 \pm 24.52$ & $29.15 \pm 17.56$ & $1.05 \pm 0.62$ & $56.41 \pm 28.12$ \\
2017 & $74.04 \pm 45.44$ & $43.02 \pm 36.92$ & $78.70 \pm 69.50$ & $17.31 \pm 18.99$ & $29.35 \pm 17.14$ & $0.96 \pm 0.53$ & $62.63 \pm 30.27$ \\
2018 & $70.37 \pm 44.47$ & $38.45 \pm 33.63$ & $74.89 \pm 83.54$ & $12.97 \pm 11.86$ & $26.59 \pm 15.74$ & $0.85 \pm 0.42$ & $64.27 \pm 30.75$ \\
2019 & $65.59 \pm 41.65$ & $37.73 \pm 33.57$ & $68.46 \pm 62.19$ & $10.82 \pm 9.40$ & $26.86 \pm 15.66$ & $0.80 \pm 0.38$ & $60.13 \pm 30.09$ \\
\hline
\end{tabular}

Values presented as means \pm standard deviation

2019. By 2019, four provinces reached the grade I $(<40 \mu \mathrm{g} /$ $\left.\mathrm{m}^{3}\right)$, standard and 15 provinces reached the grade II standard $\left(<70 \mu \mathrm{g} / \mathrm{m}^{3}\right)$.

For $\mathrm{SO}_{2}$, the highest annual average concentration of $\mathrm{SO}_{2}$ was found in Shanxi $\left(70.04 \mu \mathrm{g} / \mathrm{m}^{3}\right)$ in 2016 , and the lowest concentration was found in Hainan $\left(3.33 \mu \mathrm{g} / \mathrm{m}^{3}\right)$ in 2018 . By 2019 , only Shanxi failed to reach the grade II standard $(<60$ $\left.\mu \mathrm{g} / \mathrm{m}^{3}\right)$.

For $\mathrm{NO}_{2}$, the highest concentration was found in Beijing $\left(54.44 \mu \mathrm{g} / \mathrm{m}^{3}\right)$ in 2014 , and the lowest concentration was found in Hainan $\left(10.05 \mu \mathrm{g} / \mathrm{m}^{3}\right)$ in 2019 , and all of the provinces reached the standard $\left(<20 \mu \mathrm{g} / \mathrm{m}^{3}\right)$ in 2019 .

The annual average limitation of $\mathrm{CO}$ and $8-\mathrm{h} \mathrm{O}_{3}$ was not defined in the standard. The highest concentration of $\mathrm{CO}$ was found in Shanxi $\left(1.89 \mathrm{mg} / \mathrm{m}^{3}\right)$ in 2014 , and the lowest concentration was found in Hainan $\left(0.54 \mathrm{mg} / \mathrm{m}^{3}\right)$ in 2019 . The highest $8-\mathrm{h} \mathrm{O}_{3}$ concentration was found in Tibet $(78.97 \mu \mathrm{g} /$ $\mathrm{m}^{3}$ ) in 2014 , and the lowest concentration was found in Chongqing $\left(34.14 \mu \mathrm{g} / \mathrm{m}^{3}\right)$ in 2014 .

\section{Influence of heating on air pollutant concentration in winter}

Table 2 presents the MANOVA results of two main effects: the central heating and heating period. The main effect of central heating showed that the AQI value and the $\mathrm{PM}_{2.5}$, $\mathrm{PM}_{10}, \mathrm{SO}_{2}, \mathrm{NO}_{2}$, and $\mathrm{CO}$ concentrations were significantly higher in areas with central heating than in areas without central heating $(p<0.05)$, while no difference in $\mathrm{O}_{3}$ concentration was found between the two areas. The main effect of heating period demonstrated that the AQI value and the concentrations of the six criteria pollutants in the heating period were significantly higher than those in the non-heating period $(p<$ $0.05)$. Furthermore, the heating period and central heating of the AQI and the six pollutants had significant interaction effects $(p<0.05)$.

Figure 5 presents the results of the two-sample t-test, which compares the AQI values and concentrations of the six criteria pollutants between the heating and non-heating periods in 14 sample cities from 2014 to 2019 . The difference between the heating period and the non-heating period in the central heating area was greater than that in the area without central heating. For example, the $\mathrm{SO}_{2}$ concentration during the heating period in Changchun was 4.1 times that during the non-heating period, whereas the increase in Wuhan was only 0.7 times.

\section{Correlations between the five air pollutants}

Figure 6 shows the correlations between the five pollutants $\left(\mathrm{PM}_{2.5}, \mathrm{PM}_{10}, \mathrm{SO}_{2}, \mathrm{NO}_{2}\right.$, and $\left.\mathrm{CO}\right)$ in 14 sample cities. The $\mathrm{O}_{3}$ present in the lower atmosphere is mainly generated by photochemical reactions. Therefore, relationships between $\mathrm{O}_{3}$ and other pollutants were not independent, so the $\mathrm{O}_{3}$ was excluded from the correlation calculations.

In all 14 cities, $\mathrm{PM}_{2.5}$ was highly correlated $\left(R^{2}>0.5\right)$ with $\mathrm{PM}_{10}$, suggesting that both PMs came from the same or similar sources. Concentrations of both $\mathrm{PM}_{10}$ and $\mathrm{PM}_{2.5}$ were highly correlated with $\mathrm{SO}_{2}, \mathrm{NO}_{2}$, and $\mathrm{CO}$ in most cities, with $R^{2}$ of $0.54-0.72,0.14-0.80$, and $0.45-0.87$, respectively. The correlation coefficients of $\mathrm{SO}_{2}-\mathrm{NO}_{2}$, $\mathrm{SO}_{2}-\mathrm{CO}$, and $\mathrm{NO}_{2}-\mathrm{CO}$ were within the ranges 0.24 $0.76,0.35-0.82$, and $0.21-0.82$, respectively, with highly $\left(R^{2}>0.5\right)$, moderately $\left(0.25 \leq R^{2} \leq 0.5\right)$, or weakly $\left(0 \leq R^{2}\right.$ $\leq 0.25$ ) correlated. The correlation between $\mathrm{SO}_{2}$ and $\mathrm{CO}$ in cities located in south China, such as Haikou, was weak or moderate, suggesting that coal combustion and industrial manufacture had a relative low contribution to air pollution in this region.

\section{Discussion}

\section{Temporal variation of air pollutants}

The annual average pollutant concentration, except for $\mathrm{O}_{3}$, decreased significantly from 2014 to 2019 . According to the Statistical Communique of the People's Republic of China, from 2014 to 2017 , PM emissions decreased from 17.41 to 7.96 million tons, $\mathrm{SO}_{2}$ emissions decreased from 19.74 to 8.75 million tons, and $\mathrm{NO}_{2}$ emissions decreased from 20.78 to 12.59 million tons (National Bureal of Statistics 2019). This 

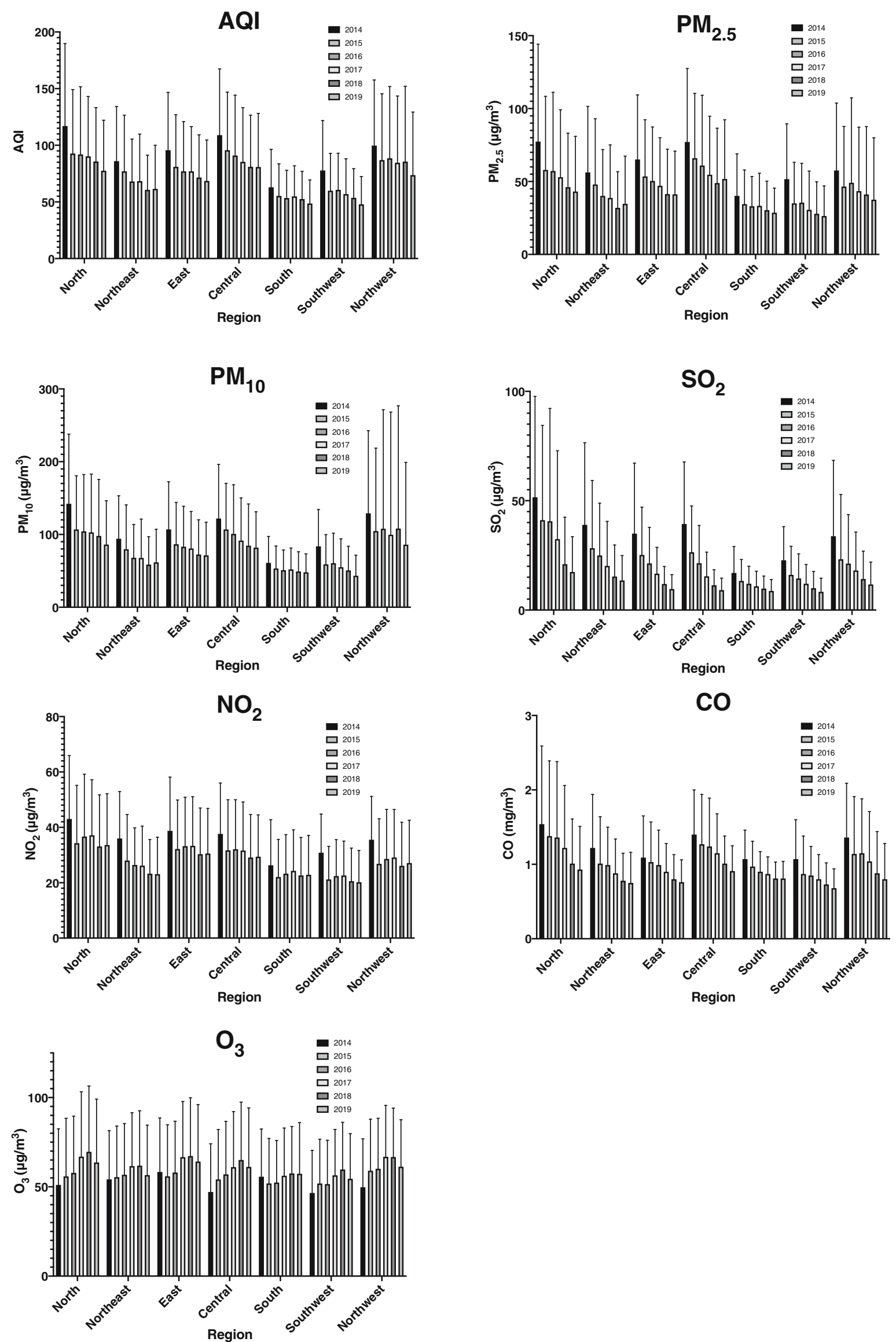

Fig. 2 Annual average value of AQI and 6 criteria pollutants concentration of seven geographical regions in China during 2014 to 2019 
is related to a series of measures taken by the Chinese government, such as shrinking the growth of harmful gas emissions, expanding production of clean energy, and continuing development of industrial structure policies and reforms (Tambo et al. 2016). Recent research (Guo et al. 2018) has indicated that the coal cap policy (a series of documents and policies released by China's State Council to support the reduction of coal consumption) resulted in significant emission reductions of $\mathrm{PM}_{2.5}, \mathrm{PM}_{10}, \mathrm{SO}_{2}, \mathrm{NO}_{2}$, and $\mathrm{CO}$, which is also consistent with the results of the present study. For comparison, only four states in the USA failed to reach the $\mathrm{PM}_{2.5}$ concentration standard, which was $12 \mu \mathrm{g} / \mathrm{m}^{3}$ in 2015 (Bennett et al. 2019). In a study covering nine countries and 16 provinces in Europe, the concentration of $\mathrm{PM}_{2.5}$ ranged from 8.1 to $43 \mu \mathrm{g} / \mathrm{m}^{3}$ (He et al. 2018). Therefore, compared with developed countries, China still has higher concentrations of PM and gaseous pollutants, and thus the government needs to continue to pay attention to air pollution in the future.
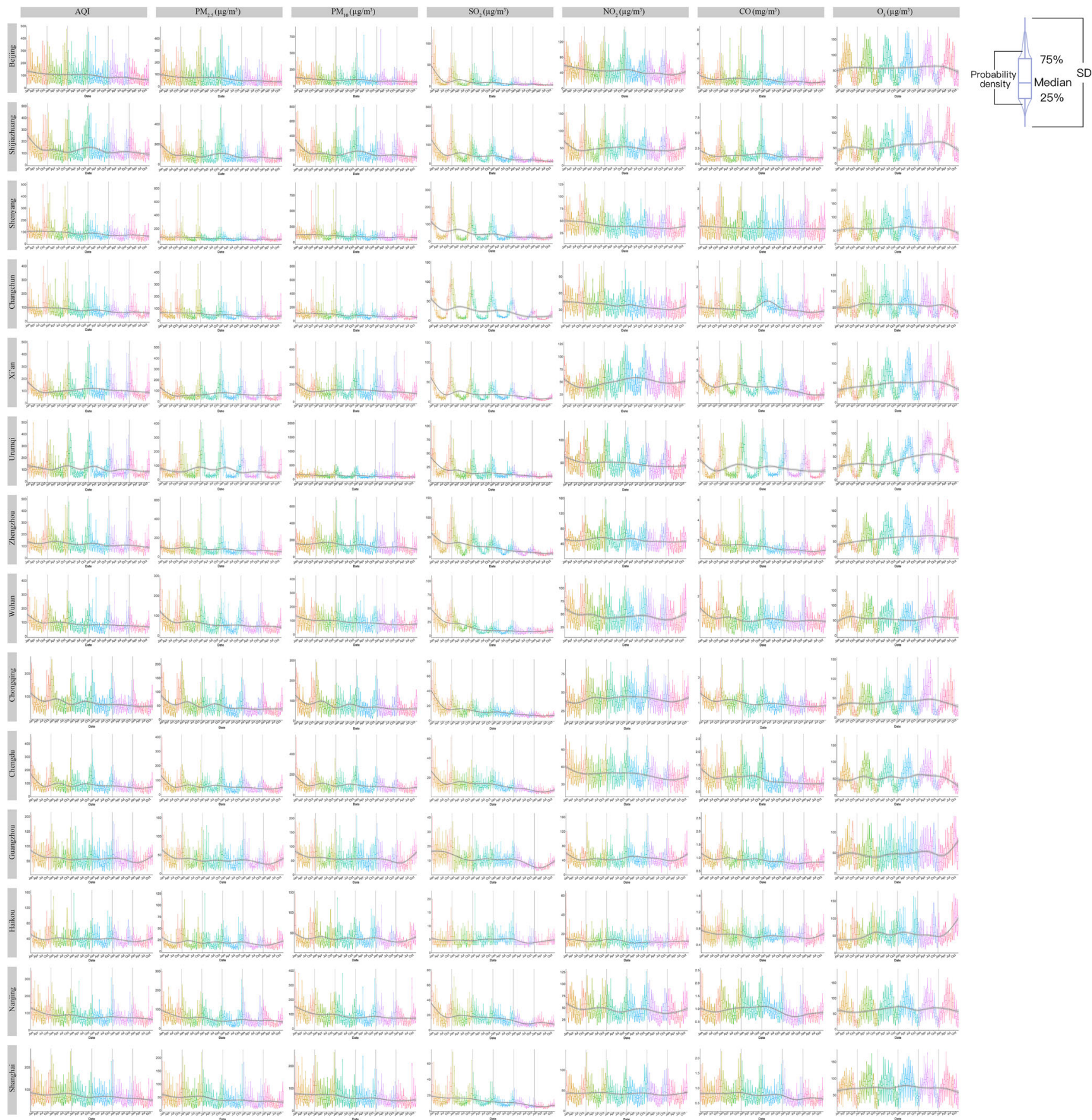

Fig. 3 Temporal variation of statistical characteristic of $\mathrm{AQI}$ and six criteria pollutants (including $\mathrm{PM}_{2.5}, \mathrm{PM}_{10}, \mathrm{SO}_{2}, \mathrm{NO}_{2}, \mathrm{CO}$, and $8 \mathrm{~h} \mathrm{O}$ ). $\mathrm{SD}$ indicates the standard deviation; $25 \%$ and $75 \%$ indicate the percentile 


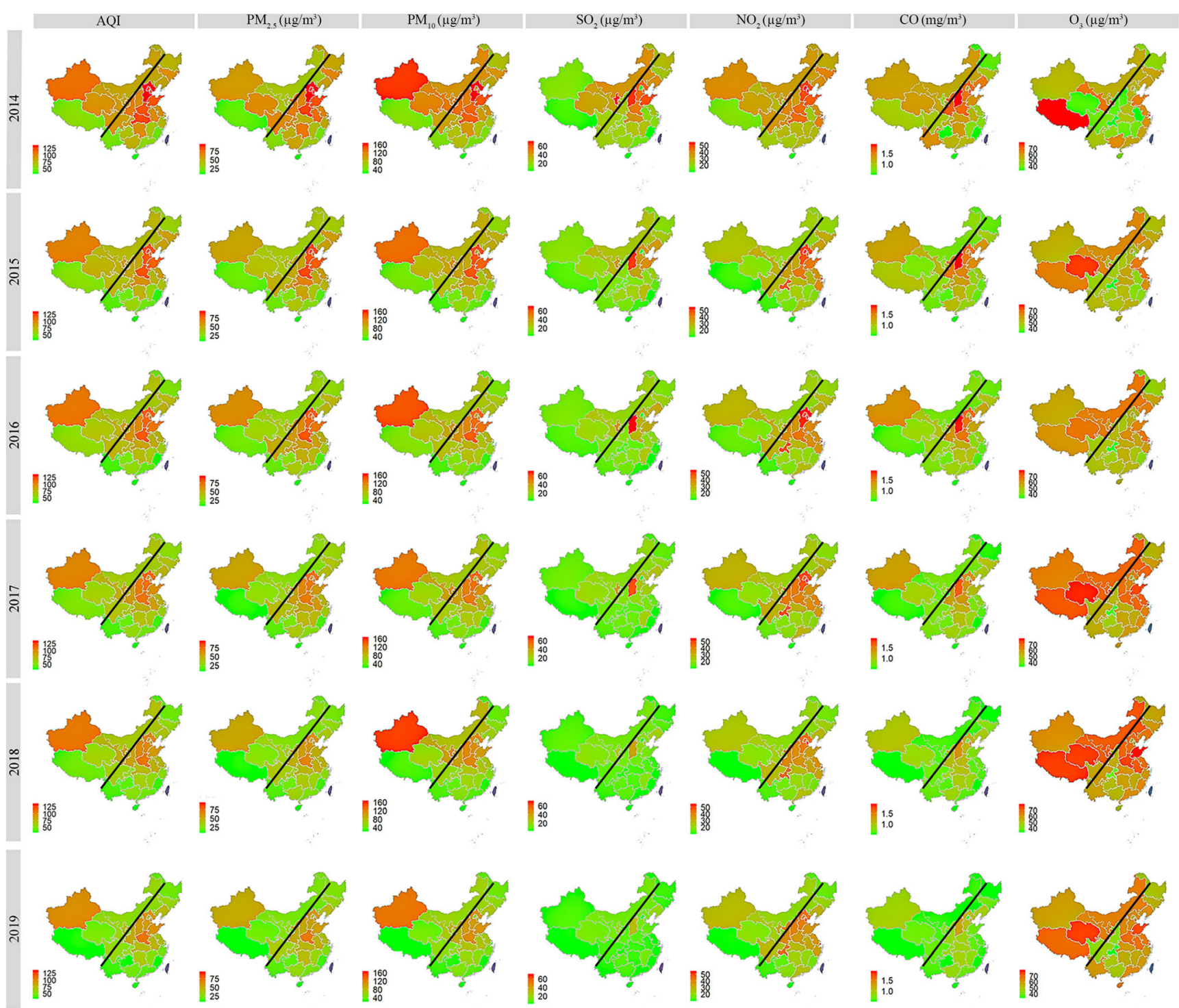

Fig. 4 Spatial distribution of annual average of $\mathrm{AQI}$ and six criteria pollutants (including $\mathrm{PM}_{2.5}, \mathrm{PM}_{10}, \mathrm{SO}_{2}, \mathrm{NO}_{2}, \mathrm{CO}$, and $8 \mathrm{~h} \mathrm{O}_{3}$ ) from 2014 to 2019 . The black line represents the Hu Huanyong line

Table 2 Effects of central heating and heating period on AQI value and 6 criteria pollutants concentration

\begin{tabular}{|c|c|c|c|c|c|c|c|c|c|c|c|c|c|c|}
\hline & \multicolumn{2}{|l|}{ AQI } & \multicolumn{2}{|c|}{$\mathrm{PM}_{2.5}\left(\mu \mathrm{g} / \mathrm{m}^{3}\right)$} & \multicolumn{2}{|c|}{$\mathrm{PM}_{10}\left(\mu \mathrm{g} / \mathrm{m}^{3}\right)$} & \multicolumn{2}{|c|}{$\mathrm{SO}_{2}\left(\mu \mathrm{g} / \mathrm{m}^{3}\right)$} & \multicolumn{2}{|c|}{$\mathrm{NO}_{2}\left(\mu \mathrm{g} / \mathrm{m}^{3}\right)$} & \multicolumn{2}{|c|}{$\mathrm{CO}\left(\mathrm{mg} / \mathrm{m}^{3}\right)$} & \multicolumn{2}{|c|}{$\mathrm{O}_{3}\left(\mu \mathrm{g} / \mathrm{m}^{3}\right)$} \\
\hline & $\mathrm{HP}$ & N-HP & HP & N-HP & HP & N-HP & HP & N-HP & HP & N-HP & HP & N-HP & HP & N-HP \\
\hline $\mathrm{CH}$ & $\begin{array}{c}124.79 \pm \\
1.21^{\S}\end{array}$ & $\begin{array}{c}80.97 \pm \\
0.56^{\#}\end{array}$ & $\begin{array}{r}90.61 \pm \\
1.10^{\S}\end{array}$ & $\begin{array}{r}44.22 \pm \\
0.47^{\#}\end{array}$ & $\begin{array}{c}136.40 \pm \\
1.55^{\S}\end{array}$ & $\begin{array}{c}89.61 \pm \\
0.78^{\#}\end{array}$ & $\begin{array}{r}42.90 \pm \\
0.65^{\S}\end{array}$ & $\begin{array}{r}13.18 \pm \\
0.15^{\#}\end{array}$ & $\begin{array}{r}53.24 \pm \\
0.35^{\S}\end{array}$ & $\begin{array}{c}36.88 \pm \\
0.18^{\#}\end{array}$ & $\begin{array}{c}1.53 \pm \\
0.81^{\S}\end{array}$ & $\begin{array}{c}0.81 \pm \\
0.0- \\
0^{\#}\end{array}$ & $\begin{array}{c}32.98 \pm \\
0.29^{*}\end{array}$ & $\begin{array}{c}69.60 \pm \\
0.41\end{array}$ \\
\hline $\mathrm{N}-\mathrm{CH}$ & $\begin{array}{c}84.67 \pm \\
0.61^{*}\end{array}$ & $\begin{array}{c}60.32 \pm \\
0.31\end{array}$ & $\begin{array}{c}59.13 \pm \\
0.51^{*}\end{array}$ & $\begin{array}{c}33.81 \pm \\
0.23\end{array}$ & $\begin{array}{c}87.45 \pm \\
0.69^{*}\end{array}$ & $\begin{array}{c}59.42 \pm \\
0.39\end{array}$ & $\begin{array}{r}14.17 \pm \\
0.14^{*}\end{array}$ & $\begin{array}{c}10.03 \pm \\
0.06\end{array}$ & $\begin{array}{r}46.32 \pm \\
0.29^{*}\end{array}$ & $\begin{array}{c}35.21 \pm \\
0.17\end{array}$ & $\begin{array}{c}1.02 \pm \\
0.00^{*}\end{array}$ & $\begin{array}{r}0.79 \pm \\
0.00\end{array}$ & $\begin{array}{c}40.55 \pm \\
0.30^{*}\end{array}$ & $\begin{array}{c}64.85 \pm \\
0.32\end{array}$ \\
\hline
\end{tabular}

Values presented as mean \pm standard error

$\mathrm{CH}$ central heating area, $\mathrm{N}$ - $\mathrm{CH}$ none-central heating area, $\mathrm{HP}$ heating period, $\mathrm{N}$ - $\mathrm{hp}$ none-heating period

${ }^{\S}$ Significant vs. N-CH and N-HP

${ }^{\text {\# }}$ Significant vs. N-CH

${ }^{*}$ Significant vs. N-HP 
Air Qual Amos Health (2021) 14:1619-1632

1627

AQ I

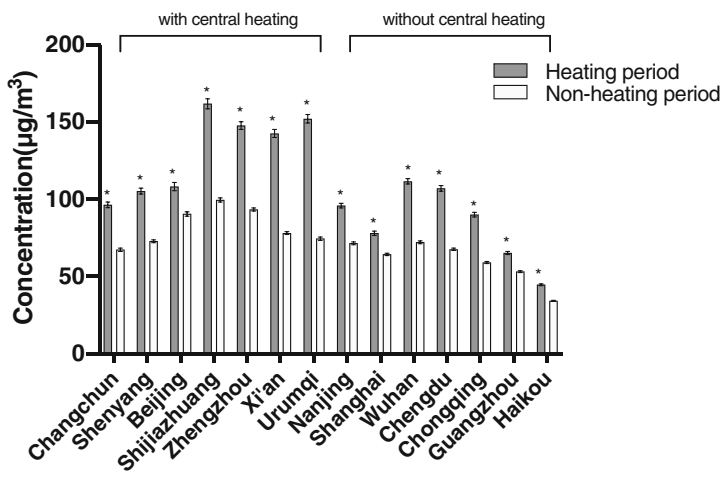

$\mathrm{PM}_{10}$
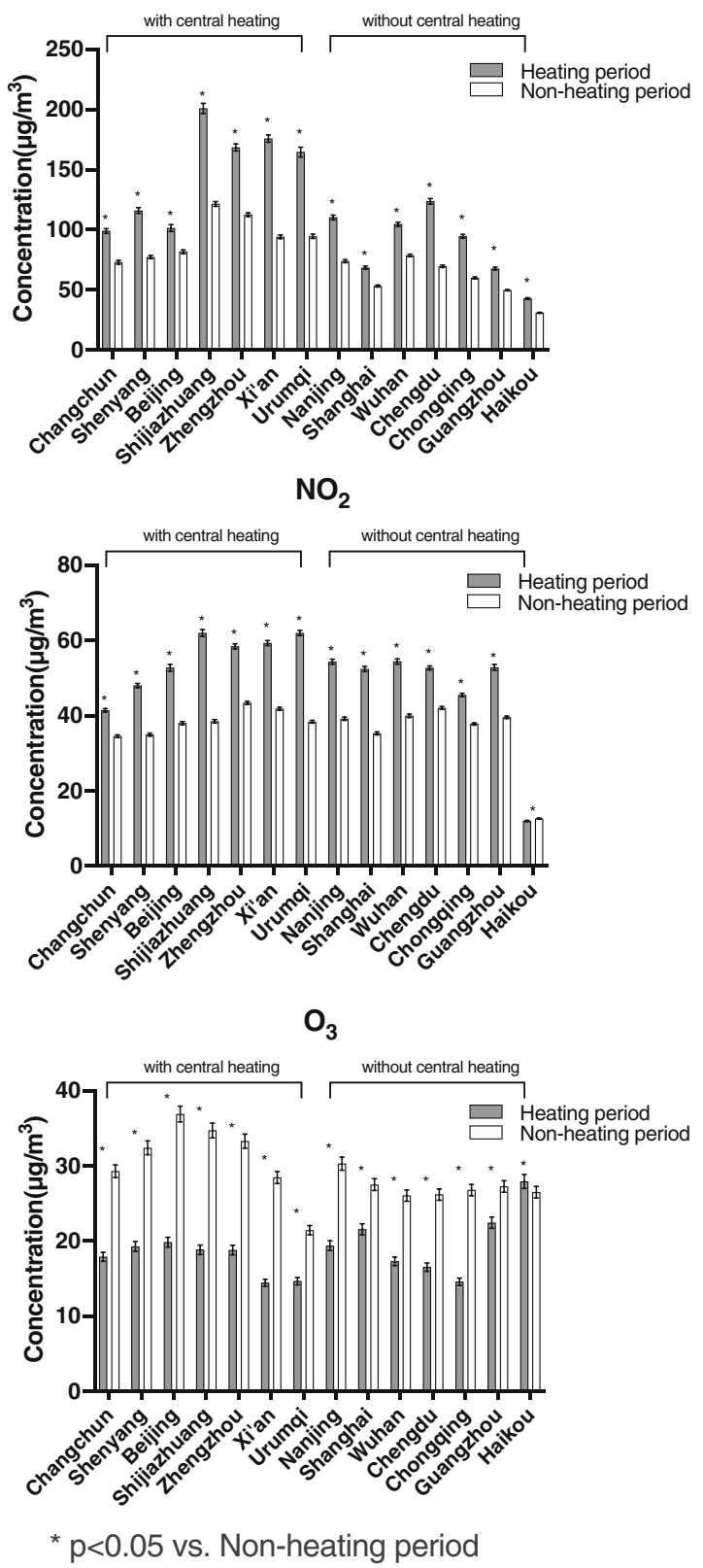

$\mathrm{PM}_{2.5}$

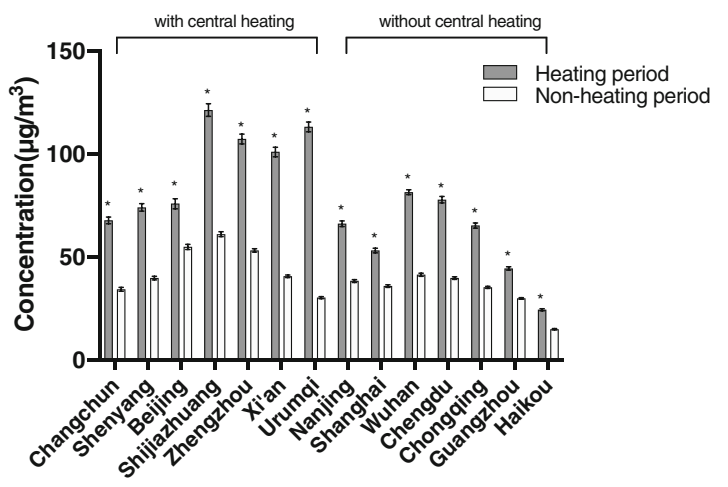

$\mathrm{SO}_{2}$
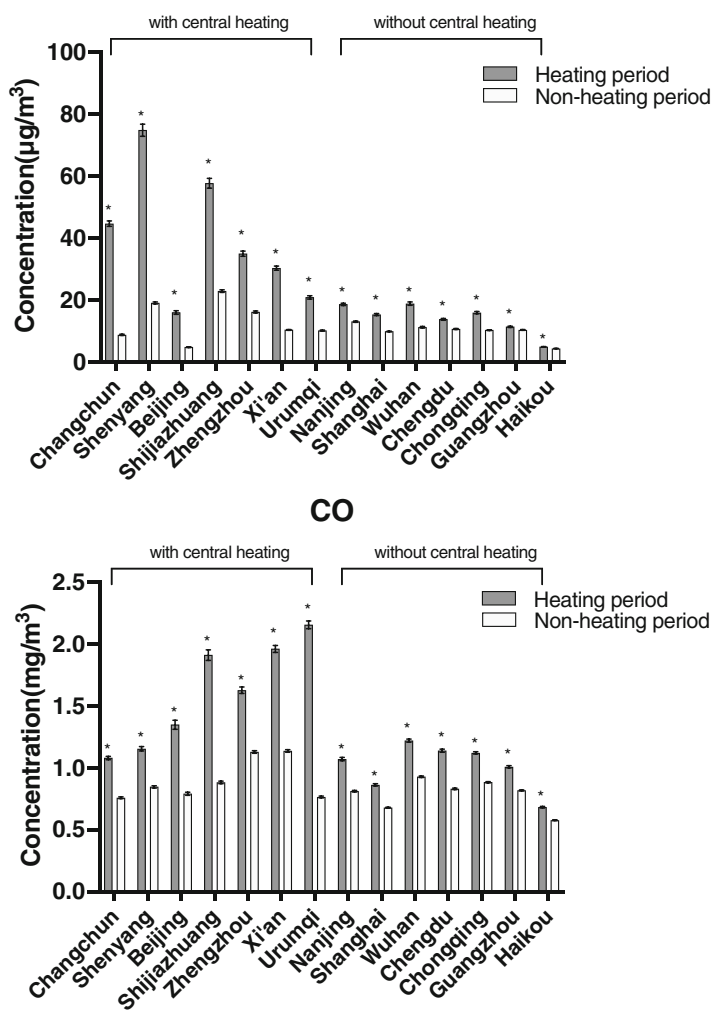

Fig. 5 Difference of average air pollutants concentration and AQI of heating and non-heating periods in 14 sample cities from 2014 to 2019. The asterisk indicates $\mathrm{p}<0.05$ vs. non-heating period

Springer 
Changes in monthly averages of $\mathrm{AQI}, \mathrm{PM}_{2.5}, \mathrm{PM}_{10}, \mathrm{CO}$, $\mathrm{SO}_{2}$, and $\mathrm{NO}_{2}$ conformed to a U-shaped pattern, with the highest values in late autumn and winter (November to February) and the lowest values in summer (June to August), which is consistent with the results of previous studies (Cui et al. 2019; Ji et al. 2019). High concentrations of pollutants in cold seasons can be explained as follows: (a) Central heating located in the north areas of the Qinling Mountains-Huaihe River Line leads to the increase in coal consumption. On the basis of the Design Code of Heating Ventilation and Air Conditioning in Civil Buildings (GB
50736-2012) (Ministry of Housing and Urban-Rural Development of the People's Republic of China 2012), central heating is only available in 13 provinces located north of the Qinling Mountains-Huaihe River Line. Residents living in Jiangsu, Anhui, and other provinces without central heating but with lower winter temperatures generally use air conditioners or individual heating equipment. Residents living in the south provinces, such as Guangdong and Hainan, do not need any heating equipment. The heating energy demands up to $8-12 \mathrm{~kg}$ of coal equivalent each winter when in central heating area. Only approximately $5 \mathrm{~kg}$ of coal equivalent is

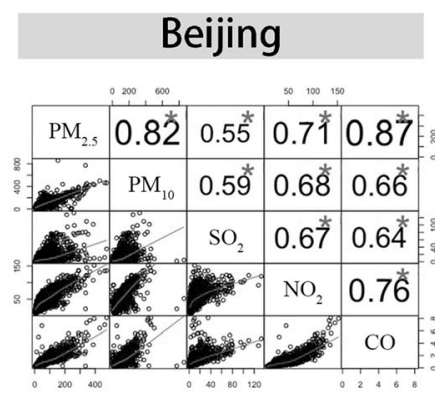

$\mathrm{Xi}^{\prime}$ an

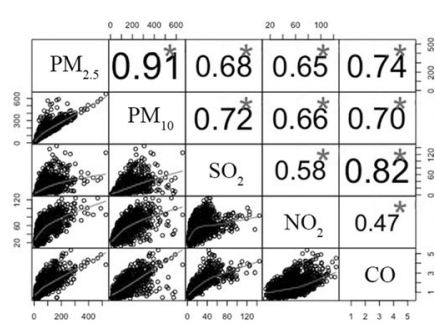

\section{Chongqing}

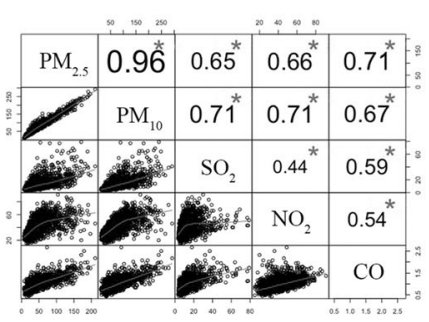

\section{Shanghai}

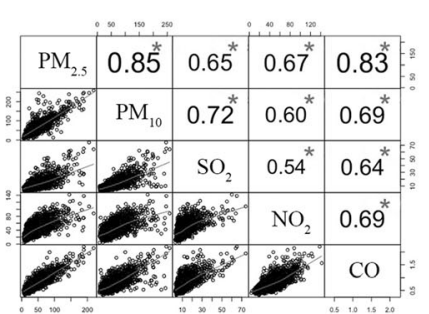

$* \mathrm{p}<0.001$

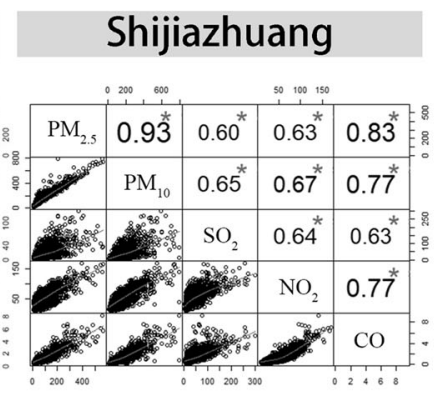

Urumqi
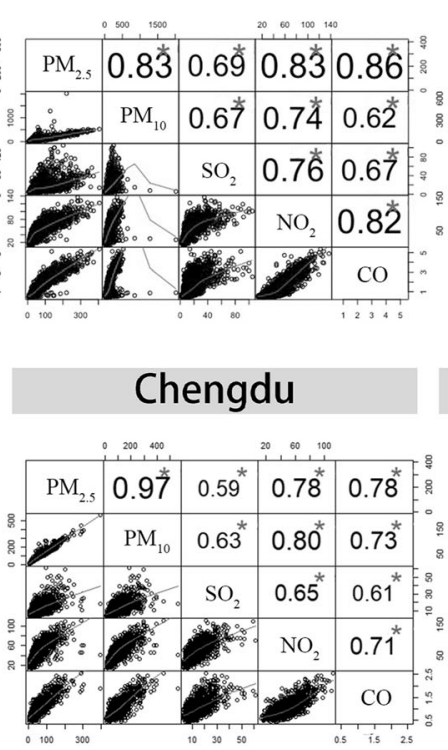

\section{西}
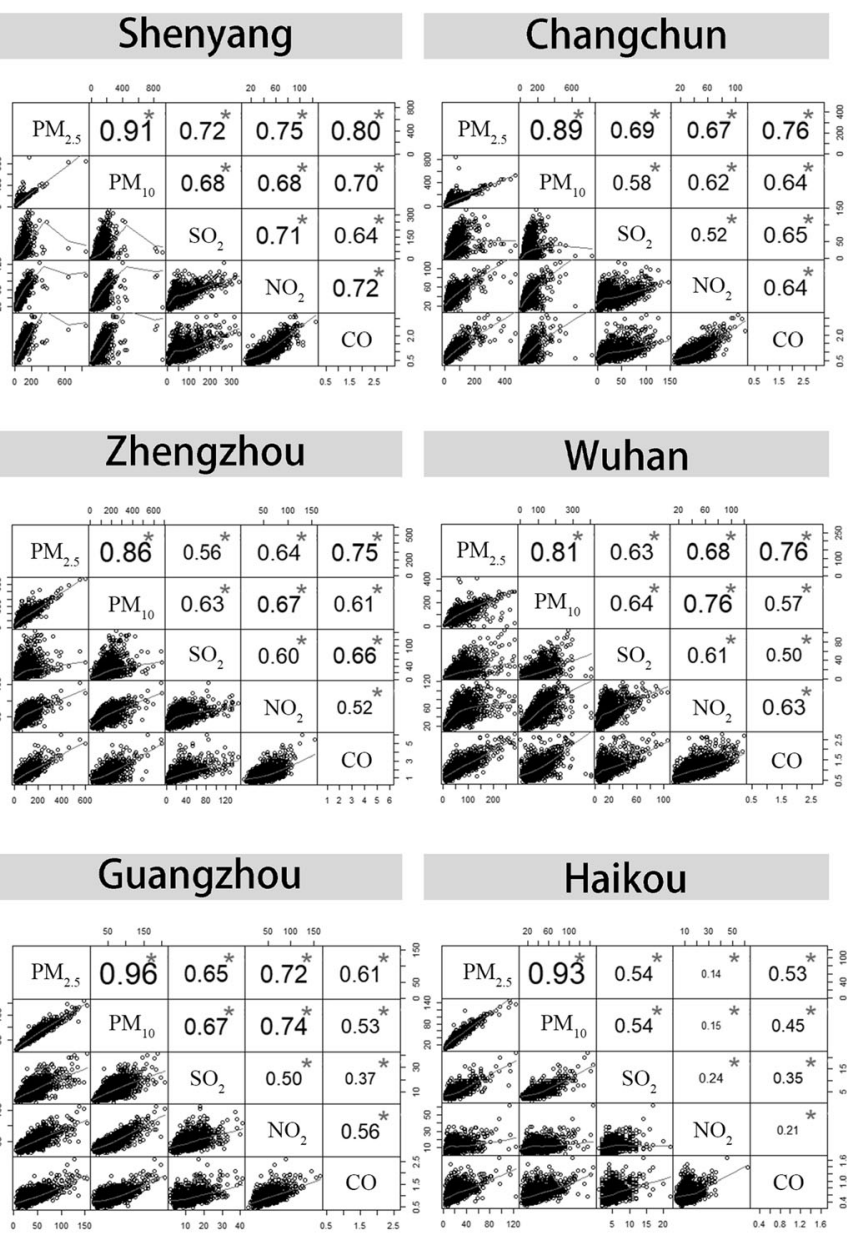

\section{Wuhan}
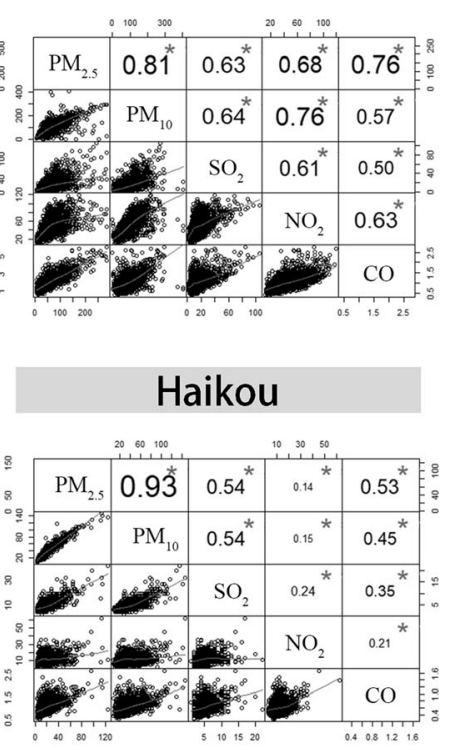

Fig. 6 Correlation relationships among the five air pollutants in the 14 representative cities from 2014 to 2019. 
required when individual heating equipment was used (Shi et al. 2018). Furthermore, the actual energy-saving effect in central heating is only $60.04 \%$ of the theoretical energysaving value (Lin and Lin 2019); (b) bad weather conditions, such as temperature inversions and low-powered air convection in winter, may hinder the diffusion and dilution of atmospheric pollutants (Zhan et al. 2017); (c) the higher atmospheric mixed layer and increased precipitation in the summer facilitated pollution dilution and deposition of atmospheric pollutants (Cui et al. 2019; Yao et al. 2019). However, the washout effect was affected by the precipitation threshold (Guo et al. 2016). And it is difficult to reach the precipitation threshold due to the decrease of precipitation in winter (Fan et al. 2020); (d) the reduction in combustion efficiency caused by the cold start of vehicle engines in winter will also lead to increased emissions (Kim and Kim 2020).

\section{Spatial variation of air pollutants}

Previous studies have found massive spatial differences in air quality and pollutant concentrations in China (Wang et al. 2017a; Ye et al. 2018), and similar differences were also found in this study. This difference may be related to the transformation of economic development models in these regions (Lin and Zhu 2020). Furthermore, it may also be related to the effectiveness of the implementation of environmental conservation and emission reduction policies in these regions (Song et al. 2020). The BTH and northwest regions have higher concentrations of $\mathrm{PM}_{2.5}$ and $\mathrm{PM}_{10}$. The $\mathrm{BTH}$ region is one of the most important economic centers in China. For the key industry in the BTH region, there were more than 6000 industrial boilers and a large number of metal basic industrial and nonmetal product sectors in 2017 (Qi et al. 2017). Moreover, there were over 5.5 million vehicles in Beijing (Qi et al. 2017; Wang et al. 2017c). High PM concentrations in northwest China were mainly from dust and aerosols in drylands (Chen et al. 2017). Sandstorms were also reported to have a major impact on the concentration of $\mathrm{PM}_{10}$ in the northwest (Zhang and Cao 2015; Guan et al. 2018). Furthermore, Miller-Schulze (Miller-Schulze et al. 2015) showed that sandstorms have no obvious effect on $\mathrm{PM}_{2.5}$. Therefore, $\mathrm{PM}_{10}$ pollution was considered more serious than $\mathrm{PM}_{2.5}$ in northwest China. Conversely, in spring and summer, the dust was transmitted to southwest through the Hexi Corridor by strong wind (Chen et al. 2017). As a result of the government's afforestation intervention measures, the conversion of farmland to forest, and reduction of desertification, air quality in northwest China has improved significantly (Du et al. 2019).

The $\mathrm{SO}_{2}, \mathrm{NO}_{2}$, and $\mathrm{CO}$ concentrations were higher in the north, northeast, and east regions and Xinjiang province. Moreover, the concentration of pollutants in some interior provinces was consistently higher than those of many coastal provinces. This was partly due to the transfer of emissionsintensive products, such as raw materials, from interior provinces to coastal areas. Furthermore, industries that produce pollutants tend to move to areas with less stringent pollution regulations and relatively low labor costs (Zhang et al. 2017; Sun et al. 2019). Even when producing the same products, interior provinces usually have higher emission intensities than those of coastal provinces. For example, the coal-fired electric power industry generates $58.4 \mathrm{~g} \mathrm{SO}_{2}$ per US\$ of electricity in Inner Mongolia, which is nearly twice that in Shanghai (Wang et al. 2017a). Early research suggests that the production of $\mathrm{PM}$ and $\mathrm{SO}_{2}$ from coal combustion in rural areas is higher than that in urban industrial areas (Zhi et al. 2017). Therefore, the government should give more attention to underdeveloped areas in the next stage of their attempts to improve air quality nationally. Additionally, pollutants can be transported from the north and central regions to the east region through long-range meteorological transportation (Sun et al. 2019; Wang et al. 2019). Ozone is a secondary pollutant generated by the photochemical reaction of nitrogen oxides (NOx) and volatile organic compounds (VOCs). Vehicle exhaust emissions and burning of biomass have been recognized as important sources of $\mathrm{O}_{3}$ (Fang et al. 2019). Areas with high NOx and VOC emissions, such as Shanghai and Guangzhou, or areas with high ultraviolet radiation, such as Tibet and Gansu, usually have higher $\mathrm{O}_{3}$ concentrations (Wang et al. 2017b). In a study on ozone sources and concentration variation in China, Liu proposed that large reductions in PM and $\mathrm{SO}_{2}$ emissions also lead to increases in urban $\mathrm{O}_{3}$ due to the complex effects of aerosols on radiation and chemical reactions, while meteorological factors also increase $\mathrm{O}_{3}$ concentrations in the southwest (Liu and Wang 2020a; Liu and Wang 2020b). Notably, some studies have found that simply reducing the concentration of NOx will lead to the increase of $\mathrm{O}_{3}$ concentration. During the COVID-19 blockade, due to the shutdown of transportation industry, the reduction of $\mathrm{NOx}$ leads to a lower $\mathrm{O}_{3}$ titration by $\mathrm{NO}$, which will lead to the increase of $\mathrm{O}_{3}$ concentration (Sicard et al. 2020; Siciliano et al. 2020). It should be noted that the $\mathrm{O}_{3}$ concentration in Hainan province is higher in the cold season, which is contrary to the seasonal characteristics of $\mathrm{O}_{3}$ concentration in other provinces. The extremely high precipitation in summer in Hainan province not only weakens the solar radiation and thus reduce the generation of $\mathrm{O}_{3}$, but also precipitation scavenges and washes out the environmental $\mathrm{O}_{3}$ concentration ( $\mathrm{Li}$ et al. 2020). Meanwhile, the $\mathrm{NO}_{2}$ that originates from vehicle emissions in the PRD in winter forms $\mathrm{NO}_{2}$ pollution events in Haikou city, and the $\mathrm{O}_{3}$ concentration in Haikou city is highly correlated with the $\mathrm{NO}_{2}$ concentration ( $\mathrm{Fu}$ et al. 2019). Therefore, we suspect that the high $\mathrm{O}_{3}$ concentration in Hainan province in winter may also be related to the meteorological transport of $\mathrm{NO}_{2}$, but this conjecture requires further study. 


\section{Sources of air pollutants}

The correlation coefficient of the different PM sizes is an important indicator for analyzing the source of pollutants. $\mathrm{PM}_{2.5}$ and $\mathrm{PM}_{10}$ are highly correlated in most areas, suggesting that these two particles come from the same or similar sources. In China, the main PM sources are combustion (such as coal-fired power plants or heaters, vehicle exhaust, biomass incineration) and dust (Yang et al. 2018; Huang et al. 2020; Yang et al. 2020). Therefore, the Chinese government should further promote clean energy policies aimed at reducing PM emissions from coal combustion and industrial production.

The $\mathrm{SO}_{2}$ source can be classified into natural and anthropogenic sources with the latter estimated to account for more than $70 \%$ of $\mathrm{SO}_{2}$ global emissions (Sun et al. 2019). Fossil fuel combustion is the main anthropogenic source of $\mathrm{SO}_{2}$, and thus the strong correlation with PM suggests that the main source of these pollutants was the combustion of fossil fuels. The correlation between $\mathrm{NO}_{2}$ and $\mathrm{PM}$ was relatively high in the present study because of the effects of vehicle exhaust emissions, fossil fuel combustion, and agriculture production (Krotkov et al. 2016; Guo et al. 2019). The results are consistent with the findings of the previous research (Yu et al. 2019). The correlation between $\mathrm{SO}_{2}$ and $\mathrm{CO}$ or $\mathrm{NO}_{2}$ was mainly affected by coal-fired fossil fuels. The strong correlation indicates that combustion has a great influence on air quality, which is also consistent with Lu's report ( $\mathrm{Lu}$ et al. 2019). The correlation between PM (both $\mathrm{PM}_{2.5}$ and $\mathrm{PM}_{10}$ ) and other gaseous pollutants in Shenyang and Urumqi was different from that in other cities, which was due to the extreme polluted weather record in these two cities. Taking Shenyang as an example, the concentration of $\mathrm{PM}_{2.5}$ was recorded as $848 \mu \mathrm{g} /$ $\mathrm{m}^{3}$ on November 8,2015 ; however, other gaseous pollutants levels were low, so the unique correlation characteristics were generated.

\section{Limitations}

This study had several limitations. First, the construction of environmental monitoring stations was not fully completed in 2014, especially in the provinces of northwestern and southwestern provinces. Therefore, the representativeness of the study in 2014 in these areas may lower than those in the follow-up study. Second, this study focused on air quality in a single city or region, and the influence of meteorological, long-distance transportation, and the transformation of pollutants have not been explored. Therefore, to further promote the improvement of China's environmental conditions in the future, it is necessary to explore the influence of pollutant transmission in the atmospheric environment and to understand the influence of physical and chemical factors on air pollutant concentrations.

\section{Conclusion}

Owing to strict control measures taken by the government, the air quality in all cities has improved significantly, but the $\mathrm{O}_{3}$ concentrations have increased gradually. Furthermore, the spatial distribution of pollutants was variable, and the air quality of north, central, northeast, and east regions were worse than those of other regions. The central heating used in areas located in the north of the Qinling Mountains-Huaihe River Line has had a negative impact on air quality. Furthermore, the main sources of air pollutants in China were fossil fuel combustion, industrial production, and motor vehicle emissions.

The air pollution in China is caused by multiple pollutants and thus shows great divergence among different regions. As a result, region-based management measures must be established. Furthermore, the influence of meteorological factors on air quality, long-distance transportation, and the transformation of pollutants should be further explored in future research.

Supplementary Information The online version contains supplementary material available at https://doi.org/10.1007/s11869-021-01043-5.

Funding This study was supported by the National Science Foundation of Liaoning Province, China [grant number: 20170541038].

Data availability statements The datasets generated during and/or analyzed during the current study are available from the corresponding author on reasonable request.

\section{Declarations}

Competing interests The authors declare no competing interests.

\section{References}

Alotaibi R, Bechle M, Marshall JD, Ramani T, Zietsman J, Nieuwenhuijsen MJ, Khreis H (2019) Traffic related air pollution and the burden of childhood asthma in the contiguous United States in 2000 and 2010. Environ Int 127:858-867. https://doi.org/10. 1016/j.envint.2019.03.041

Bennett JE, Tamura-Wicks H, Parks RM, Burnett RT, Pope CA 3rd, Bechle MJ, Marshall JD, Danaei G, Ezzati M (2019) Particulate matter air pollution and national and county life expectancy loss in the USA: a spatiotemporal analysis. PLoS Med 16(7): e1002856. https://doi.org/10.1371/journal.pmed.1002856

Chen S, Huang J, Kang L, Wang H, Ma X, He Y, Yuan T, Yang B, Huang Z, Zhang G (2017) Emission, transport, and radiative effects of mineral dust from the Taklimakan and Gobi deserts: comparison of measurements and model results. Atmos Chem Phys 17(3):1-43. https://doi.org/10.5194/acp-17-2401-2017

Core Team R (2020) R: A language and environment for statistical computing. R Foundation for Statistical Computing, Vienna

Cui J, Lang J, Chen T, Mao S, Cheng S, Wang Z, Cheng N (2019) A framework for investigating the air quality variation characteristics based on the monitoring data: case study for Beijing during 2013- 
2016. J Environ Sci 81:225-237. https://doi.org/10.1016/j.jes.2019. 01.009

Du J, Zhang X, Huang T, Gao H, Mo J, Mao X, Ma J (2019) Removal of PM2. 5 and secondary inorganic aerosols in the North China Plain by dry deposition. Sci Total Environ 651:2312-2322. https://doi. org/10.1016/j.scitotenv.2018.10.024

Fan H, Zhao C, Yang Y (2020) A comprehensive analysis of the spatiotemporal variation of urban air pollution in China during 2014 2018. Atmos Environ 220:117066. https://doi.org/10.1016/j. atmosenv.2019.117066

Fang X, Park S, Saito T, Tunnicliffe R, Ganesan AL, Rigby M, Li S, Yokouchi Y, Fraser PJ, Harth CM (2019) Rapid increase in ozonedepleting chloroform emissions from China. Nat Geosci 12:89-93

Fu C, Dan L, Tang J, Yang W (2019) Spatiotemporal variation of no 2 and sub-regional transport during winter pollution events in Haikou, China. J Trop Meteorol 25:365-374

Guan Q, Li F, Yang L, Zhao R, Yang Y, Luo H (2018) Spatial-temporal variations and mineral dust fractions in particulate matter mass concentrations in an urban area of northwestern China. J Environ Manag 222:95-103. https://doi.org/10.1016/j.jenvman.2018.05.064

Guo L-C, Zhang Y, Lin H, Zeng W, Liu T, Xiao J, Rutherford S, You J, Ma W (2016) The washout effects of rainfall on atmospheric particulate pollution in two Chinese cities. Environ Pollut 215:195-202. https://doi.org/10.1016/j.envpol.2016.05.003

Guo X, Zhao L, Chen D, Jia Y, Zhao N, Liu W, Cheng S (2018) Air quality improvement and health benefit of PM 2.5 reduction from the coal cap policy in the Beijing-Tianjin-Hebei (BTH) region, China. Environ Sci Pollut Res 25:32709-32720. https://doi.org/ 10.1007/s11356-018-3014-y

Guo H, Gu X, Ma G, Shi S, Wang W, Zuo X, Zhang X (2019) Spatial and temporal variations of air quality and six air pollutants in China during 2015-2017. Sci Rep 9:15201. https://doi.org/10.1038/ s41598-019-50655-6

He L, Chen H, Rangognio J, Yahyaoui A, Colin P, Wang J, Daële V, Mellouki A (2018) Fine particles at a background site in Central France: chemical compositions, seasonal variations and pollution events. Sci Total Environ 612:1159-1170. https://doi.org/10.1016/ j.scitotenv.2017.08.273

Huang R-J, Zhang Y, Bozzetti C, Ho K-F, Cao J-J, Han Y, Daellenbach KR, Slowik JG, Platt SM, Canonaco F (2014) High secondary aerosol contribution to particulate pollution during haze events in China. Nature 514:218-222. https://doi.org/10.1038/nature13774

Huang J, Pan X, Guo X, Li G (2018) Health impact of China's Air Pollution Prevention and Control Action Plan: an analysis of national air quality monitoring and mortality data. Lancet Planet Health 2: e313-e323. https://doi.org/10.1016/S2542-5196(18)30141-4

Huang H-C, Lin FC-F, Wu M-F, Nfor ON, Hsu S-Y, Lung C-C, Ho C-C, Chen C-Y, Liaw Y-P (2019) Association between chronic obstructive pulmonary disease and PM2. 5 in Taiwanese nonsmokers. Int J Hyg Environ Health 222:884-888. https://doi.org/10.1016/j.ijheh. 2019.03.009

Huang Y, Wang L, Zhang S, Zhang M, Wang J, Cheng X, Li T, He M, Ni S (2020) Source apportionment and health risk assessment of air pollution particles in eastern district of Chengdu. Environ Geochem Health 42(7):2251-2263. https://doi.org/10.1007/ s10653-019-00495-0

Ji W, Wang Y, Zhuang D (2019) Spatial distribution differences in PM2.5 concentration between heating and non-heating seasons in Beijing, China. Environ Pollut 248:574-583. https://doi.org/10. 1016/j.envpol.2019.01.002

Kim S-U, Kim K-Y (2020) Physical and chemical mechanisms of the daily-to-seasonal variation of PM10 in Korea. Sci Total Environ 712:136429. https://doi.org/10.1016/j.scitotenv.2019.136429

Krotkov NA, McLinden CA, Li C, Lamsal LN, Celarier EA, Marchenko SV, Swartz WH, Bucsela EJ, Joiner J, Duncan BN (2016) Aura OMI observations of regional SO2 and NO2 pollution changes from 2005 to 2015. Atmos Chem Phys 16:4605. https:// doi.org/10.5194/acp-16-4605-2016

Li R, Wang Z, Cui L, Fu H, Zhang L, Kong L, Chen W, Chen J (2019) Air pollution characteristics in China during 2015-2016: spatiotemporal variations and key meteorological factors. Sci Total Environ 648:902-915. https://doi.org/10.1016/j.scitotenv.2018.08.181

Li R, Cui L, Hongbo F, Li J, Zhao Y, Chen J (2020) Satellite-based estimation of full-coverage ozone $(\mathrm{O} 3)$ concentration and health effect assessment across Hainan Island. J Clean Prod 244:118773. https://doi.org/10.1016/j.jclepro.2019.118773

Lin J, Lin B (2019) The actual heating energy conservation in China: evidence and policy implications. Energy Build 190:195-201. https://doi.org/10.1016/j.enbuild.2019.03.004

Lin B, Zhu J (2020) Policy effect of the clean air action on green development in Chinese cities. J Environ Manag 258:110036. https://doi. org/10.1016/j.jenvman.2019.110036

Liu Y, Wang T (2020a) Worsening urban ozone pollution in China from 2013 to 2017 - Part 1: the complex and varying roles of meteorology. Atmos Chem Phys 20:6305-6321. https://doi.org/10.5194/acp20-6305-2020

Liu Y, Wang T (2020b) Worsening urban ozone pollution in China from 2013 to 2017 - Part 2: the effects of emission changes and implications for multi-pollutant control. Atmos Chem Phys 20:6323-6337. https://doi.org/10.5194/acp-20-6323-2020

Lu X, Chen Y, Huang Y, Lin C, Li Z, Fung JC, Lau AK (2019) Differences in concentration and source apportionment of PM2.5 between 2006 and 2015 over the PRD region in southern China. Sci Total Environ 673:708-718. https://doi.org/10.1016/j. scitotenv.2019.03.452

Miller-Schulze JP, Shafer M, Schauer JJ, Heo J, Solomon PA, Lantz J, Artamonova M, Chen B, Imashev S, Sverdlik L (2015) Seasonal contribution of mineral dust and other major components to particulate matter at two remote sites in Central Asia. Atmos Environ 119: 11-20. https://doi.org/10.1016/j.atmosenv.2015.07.011

Ministry of Ecology and Environment of People's Republic of China (2012) Technical regulation on ambient air quality index (on trial). http://www.mee.gov.cn/ywgz/fgbz/bz/bzwb/jcffbz/201203/ t20120302 224166.shtml. Accessed 23 Jul 2020

Ministry of Ecology and Environment of the People's Republic of China (2012) Ambient air quality standards. http://www.mee.gov.cn/ ywgz/fgbz/bz/bzwb/dqhjbh/dqhjzlbz/201203/t20120302_224165. shtml. Accessed 23 Jul 2020

Ministry of Housing and Urban-Rural Development of the People's Republic of China (2012) Design code for heating ventilation and air conditioning of civil buildings. http://www.mohurd.gov.cn/wjfb/ 201203/t20120327_209265.html. Accessed 23 Jul 2020

National Bureal of Statistics (2019) Statistical communique of the People's Republic of China. http://data.stats.gov.cn/easyquery. $\mathrm{htm} ? \mathrm{cn}=\mathrm{C} 01 \& \mathrm{zb}=\mathrm{A} 0 \mathrm{C} 05 \& \mathrm{sj}=2015$. Accessed $23 \mathrm{Jul} 2020$

Qi J, Zheng B, Li M, Yu F, Chen C, Liu F, Zhou X, Yuan J, Zhang Q, He $\mathrm{K}$ (2017) A high-resolution air pollutants emission inventory in 2013 for the Beijing-Tianjin-Hebei region, China. Atmos Environ 170:156-168. https://doi.org/10.1016/j.atmosenv.2017.09.039

Shi Y, Wang G, Gao X, Xu Y (2018) Effects of climate and potential policy changes on heating degree days in current heating areas of China. Sci Rep 8:1-13. https://doi.org/10.1038/s41598-018-28411$\mathrm{Z}$

Sicard P, Marco AD, Agathokleous E, Feng Z, Xu X, Paoletti E, Rodriguez JJD, Calatayud V (2020) Amplified ozone pollution in cities during the COVID-19 lockdown. Sci Total Environ 735: 139542. https://doi.org/10.1016/j.scitotenv.2020.139542

Siciliano B, Dantas G, da Silva CM, Arbilla G (2020) Increased ozone levels during the COVID-19 lockdown: analysis for the city of Rio de Janeiro, Brazil. Sci Total Environ 737:139765. https://doi.org/ 10.1016/j.scitotenv.2020.139765 
Song C, Wu L, Xie Y, He J, Chen X, Wang T, Lin Y, Jin T, Wang A, Liu Y (2017) Air pollution in China: status and spatiotemporal variations. Environ Pollut 227:334-347. https://doi.org/10.1016/j. envpol.2017.04.075

Song Y, Li Z, Yang T, Xia Q (2020) Does the expansion of the joint prevention and control area improve the air quality? - evidence from China's Jing-Jin-Ji region and surrounding areas. Sci Total Environ 706:136034. https://doi.org/10.1016/j.scitotenv.2019. 136034

Sun X, Luo X-S, Xu J, Zhao Z, Chen Y, Wu L, Chen Q, Zhang D (2019) Spatio-temporal variations and factors of a provincial PM 2.5 pollution in eastern China during 2013-2017 by geostatistics. Sci Rep 9:1-10

Tambo E, Duo-Quan W, Zhou X-N (2016) Tackling air pollution and extreme climate changes in China: implementing the Paris climate change agreement. Environ Int 95:152-156 https://doi.org/10. 1016/j.envint.2016.04.010

The National People's Congress of the People's Republic of China (2018) People's Republic of China Environmental Protection Tax Law. http://www.gov.cn/zhengce/content/2017-12/30/content 5251797.htm. Accessed 23 Jul 2020

Wang H, Zhang Y, Zhao H, Lu X, Zhang Y, Zhu W, Nielsen CP, Li X, Zhang Q, Bi J (2017a) Trade-driven relocation of air pollution and health impacts in China. Nat Commun 8:1-7

Wang T, Xue L, Brimblecombe P, Lam YF, Li L, Zhang L (2017b) Ozone pollution in China: a review of concentrations, meteorological influences, chemical precursors, and effects. Sci Total Environ 575:1582-1596. https://doi.org/10.1016/j.scitotenv.2016.10.081

Wang Y, Liu H, Mao G, Zuo J, Ma J (2017c) Inter-regional and sectoral linkage analysis of air pollution in Beijing-Tianjin-Hebei (Jing-JinJi) urban agglomeration of China. J Clean Prod 165:1436-1444. https://doi.org/10.1016/j.jclepro.2017.07.210

Wang Y, Duan X, Wang L (2019) Spatial-temporal evolution of PM2. 5 concentration and its socioeconomic influence factors in Chinese cities in 2014-2017. Int J Environ Res Public Health 16:985. https://doi.org/10.3390/ijerph16060985

Xia Y, Niu Y, Cai J, Lin Z, Liu C, Li H, Chen C, Song W, Zhao Z, Chen $\mathrm{R}$ (2018) Effects of personal short-term exposure to ambient ozone on blood pressure and vascular endothelial function: a mechanistic study based on DNA methylation and metabolomics. Environ Sci Technol 52:12774-12782. https://doi.org/10.1021/acs.est.8b03044

Yang X, Jiang L, Zhao W, Xiong Q, Zhao W, Yan X (2018) Comparison of ground-based PM2.5 and PM10 concentrations in China, India, and the US. Int J Environ Res Public Health 15:1382. https://doi.org/ 10.3390/ijerph15071382

Yang X, Liu S, Shao P, He J, Liang Y, Zhang B, Liu B, Liu Y, Tang G, Ji D (2020) Effectively controlling hazardous airborne elements: insights from continuous hourly observations during the seasons with the most unfavorable meteorological conditions after the implementation of the APPCAP. J Hazard Mater 387:121710. https:// doi.org/10.1016/j.jhazmat.2019.121710

Yao Y, He C, Li S, Ma W, Li S, Yu Q, Mi N, Yu J, Wang W, Yin L (2019) Properties of particulate matter and gaseous pollutants in Shandong, China: daily fluctuation, influencing factors, and spatiotemporal distribution. Sci Total Environ 660:384-394. https://doi. org/10.1016/j.scitotenv.2019.01.026

Yap J, Ng Y, Yeo KK, Sahlén A, Lam CSP, Lee V, Ma S (2019) Particulate air pollution on cardiovascular mortality in the tropics: impact on the elderly. Environ Health 18:34. https://doi.org/10. 1186/s12940-019-0476-4

Ye W-F, Ma Z-Y, Ha X-Z (2018) Spatial-temporal patterns of PM2.5 concentrations for 338 Chinese cities. Sci Total Environ 631:524 533. https://doi.org/10.1016/j.scitotenv.2018.03.057

Yin P, Chen R, Wang L, Meng X, Liu C, Niu Y, Lin Z, Liu Y, Liu J, Qi J (2017) Ambient ozone pollution and daily mortality: a nationwide study in 272 Chinese cities. Environ Health Perspect 125:117006. https://doi.org/10.1289/EHP1849

Yu G, Jia Y, He N, Zhu J, Chen Z, Wang Q, Piao S, Liu X, He H, Guo X (2019) Stabilization of atmospheric nitrogen deposition in China over the past decade. Nat Geosci 12:424-429. https://doi.org/10. 1038/s41561-019-0352-4

Zeng Y, Cao Y, Qiao X, Seyler BC, Tang Y (2019) Air pollution reduction in China: recent success but great challenge for the future. Sci Total Environ 663:329-337.https://doi.org/10.1016/j.scitotenv. 2019.01.262

Zhan D, Kwan M-P, Zhang W, Wang S, Yu J (2017) Spatiotemporal variations and driving factors of air pollution in China. Int $\mathrm{J}$ Environ Res Public Health 14:1538. https://doi.org/10.3390/ ijerph14121538

Zhang Y-L, Cao F (2015) Fine particulate matter (PM 2.5) in China at a city level. Sci Rep 5:14884

Zhang Q, Jiang X, Tong D, Davis SJ, Zhao H, Geng G, Feng T, Zheng B, Lu Z, Streets DG (2017) Transboundary health impacts of transported global air pollution and international trade. Nature 543: 705-709. https://doi.org/10.1038/nature21712

Zhi G, Zhang Y, Sun J, Cheng M, Dang H, Liu S, Yang J, Zhang Y, Xue Z, Li S (2017) Village energy survey reveals missing rural raw coal in northern China: significance in science and policy. Environ Pollut 223:705-712. https://doi.org/10.1016/j.envpol.2017.02.009

Publisher's note Springer Nature remains neutral with regard to jurisdictional claims in published maps and institutional affiliations. 